\title{
口蓋扁桃転移により判明した肝細胞癌例
}

\author{
清野 由輩1) -中山 明仁2) - 竹田 昌彦2) ・橋本 大門2) \\ 宮本 俊輔 2 - 八尾 和雄 3 - 岡本 牧人 2)
}

\section{Hepatocellular Carcinoma Metastasized to Palatine Tonsil: A Case Report}

\author{
Yutomo Seino \\ (Yamato City Hospital) \\ Meijin Nakayama, Masahiko Takeda, Daimon Hashimoto, \\ Shunsuke Miyamoto and Makito Okamoto \\ (Kitasato University School of Medicine) \\ Kazuo Yao \\ (Yokohama Clinic of Kanagawa Dental University)
}

\begin{abstract}
We experienced a case of hepatocellular carcinoma metastasized to the palatine tonsil. The patient was a 55-year-old man. His chief complaint was pharyngeal discomfort. An exophytic tumorous mass was found occupying the left palatine tonsil. We conducted a biopsy. The pathology was not squamous cell carcinoma nor malignant lymphoma, therefore, we conducted various immunostainings. It was finally diagnosed as metastasis from hepatocellular carcinoma. Subsequent examinations identified that the tumor had invaded the entire liver. This tumor is likely to metastasize through the hematogenous pathway. In general, metastasis to the head and neck region from any systemic primary tumor indicates a poor prognosis. However, treatment options should not be excluded, especially if the QOL of the patient can be improved.
\end{abstract}

Key words : hepatocellular carcinoma, palatine tonsil, metastasis

はじめに

肝細胞癌は頭頸部領域のなかで頸部リンパ節以外への 転移は頻度が少なく1)，特に口蓋扁桃への転移はまれで ある2).今回われわれは口蓋扁桃へ転移した肝細胞癌の 1 例を経験した．診断方法を中心に考察を行ったので報 告する.

\section{症例}

患者： 55 歳，男性.

主訴：咽頭違和感.

現病歴：6カ月前より咽頭違和感を自覚した. 口腔から の出血も認めていたが放置していた，その後，食事摂取 が困難となり，2カ月前より全身倦急感が著明になった。 近医耳鼻咽喉科を受診し，左扁桃腫瘍を指摘され精查加 療目的にて当科を紹介され受診した。

1）大和市立病院耳鼻咽喉科

2) 北里大学耳鼻咽喉科学教室

3）神奈川歯科大学臨床医学系耳鼻咽喉科講座 


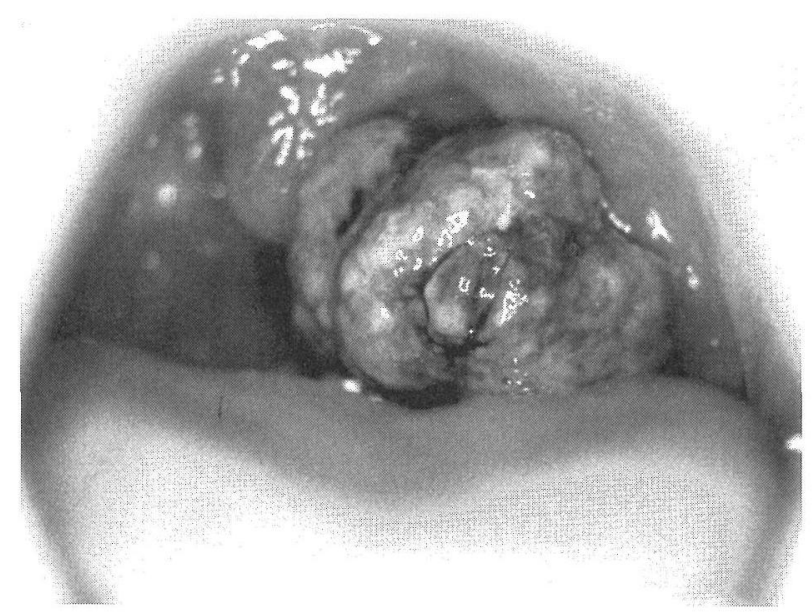

図 1 左口蓋扁桃の所見（初診時）

正常の陰窩構造は認められず, 表面は不整である。表面 全体は白苔で覆われている。

既往歴: 糖尿病（経口血糖降下剂内服中）, 高血圧（未 治療), 肝機能障害 ( 2 年前より指摘される), 輸血の既 往なし。

喫煙歴：なし。

飲酒歴：焼酎約 $600 \sim 800 \mathrm{ml} /$ 日.

初診時現症：耳鼻咽喉科学的所見としては, 左口蓋扁 桃は全体的に腫大し，正常の陰窩構造は認められず, 表 面は不整であった（図 1)。表面は白苔で覆われており， 易出血性であった。左耳下部に表面は平滑で弾性硬，可 動性不良の $2 \mathrm{~cm}$ 大のリンパ節を触知した。

全身状態は軽度の低栄養状態, 眼瞼結膜は貧血様で眼 球結膜に黄染はみられなかった。心音, 呼吸音は正常で
あった。肝腫大を右季肋部に二横指触知し，圧痛を認め た。胸骨柄皮下に硬い $3 \mathrm{~cm}$ 大の腫瘤を認めた。

血液学的検查所見（表 1): 赤血球 186 万 $/ \mu \mathrm{l}, \mathrm{Hb} 5.7 \mathrm{~g} /$ d1 と著明な正球性正色素性の貧血がみられ, 生化学検查 では肝機能の低下と BUN, クレアチニンの上昇を認め た. $\mathrm{HB}_{\mathrm{S}}$ 抗原が陽性, HCV 抗体は陰性であった。

画像検査所見: 胸部 X 線単純写真にて右横隔膜高位を 認めた。頸部造影 CT では造影効果のない左口蓋扁桃の 腫大を認めた。また左側頸部と左後頸三角に低吸収域の あるリンパ節腫大を認めた。腹部 CT では肝内の全区域 にわたる多発性の低吸収域と腹水の貯留を認めた(図2)。 胸部 CT では胸骨に骨破壊および周囲軟部組織の腫脹を 認めたほ办，脊椎（Th11, L1, 2, 3, 5）にも骨破壊を伴う 転移巣を認めた。

病理組織学的検查 : 左口蓋扁桃の病変加生検を行っ た. HE 染色（図 3) では高度の異型核および淡明な細胞 質を有する腫惕細胞が充実性に増殖する像を認めた。一 部では, 索状配列を示していた。 また各種免疫染色を行っ た. CAM5. 2 免疫染色（図 4) では上皮系免疫染色の細 胞膜と細胞質に染色性を認めた。また間葉系免疫染色の ビメンチンは染色されなかった. Hepatocyte 免疫染色 （図5）では細胞質中には褐色矤色される顆粒を認めた。 AFP 免疫染色 (図 6) では細胞質は顆粒状, 茶褐色に染色 される部分を認めた。

入院後経過 : 貧血の改善と全身の精查を目的として入 院し, 貧血に対し人赤血球濃厚液 8 単位を輸血した。経 口摂取は可能であったが，補助的に末梢静脈から補液を 行った。各種検查結果より, 肝細胞癌の扁桃転移おうび

表 1 血液検查結果

\begin{tabular}{|c|c|c|c|}
\hline 血算 & 凝固系 & 生化学 & \\
\hline WBC $12100 / \mu 1$ & PT $9.6 \mathrm{sec}$ & $\mathrm{TP} 6.5 \mathrm{mg} / \mathrm{dl}$ & BUN 58 mg/dl \\
\hline $\mathrm{RBC} 186$ 万/ $\mu \mathrm{l}$ & APTT $33.4 \mathrm{sec}$ & Alb $2.9 \mathrm{mg} / \mathrm{dl}$ & $\mathrm{Cr} 1.42 \mathrm{mg} / \mathrm{d}$ \\
\hline $\mathrm{Hb} 5.7 \mathrm{~g} / \mathrm{dl}$ & PT-INR 0.79 & T. Bil $1.0 \mathrm{mg} / \mathrm{dl}$ & $\mathrm{Na} 138 \mathrm{mEq} / 1$ \\
\hline Ht $17.6 \%$ & & GOT 94 IU/1 & $\mathrm{K} 4.9 \mathrm{mEq} / 1$ \\
\hline MCV $94.6 \mathrm{fl}$ & & GPT $68 \mathrm{IU} / 1$ & $\mathrm{Cl} 103 \mathrm{mEq} / 1$ \\
\hline $\mathrm{MCH} 30.6 \mathrm{pg}$ & & ALP $1070 \mathrm{IU} / 1$ & $\mathrm{Ca} 8.6 \mathrm{mg} / \mathrm{dl}$ \\
\hline MCHC $32.5 \%$ & & ChE $145 \mathrm{IU} / 1$ & $\mathrm{FE}$ (血清鉄) $24 \mu \mathrm{g} / \mathrm{dl}$ \\
\hline Plt 43.6 万/ $/ \mu 1$ & & $\gamma$-GTP 481 IU/1 & CRP 11. $018 \mathrm{mg} / \mathrm{dl}$ \\
\hline \multirow[t]{3}{*}{ Reti $87.6 \times 10^{3} / \mu 1$} & & LDH $330 \mathrm{IU} / 1$ & HBS-Ag (+) \\
\hline & & T. Chol $161 \mathrm{mg} / \mathrm{dl}$ & HCV-Ab (-) \\
\hline & & TG 173 mg/dl & S-IL2R $1180 \mathrm{U} / \mathrm{ml}$ \\
\hline
\end{tabular}




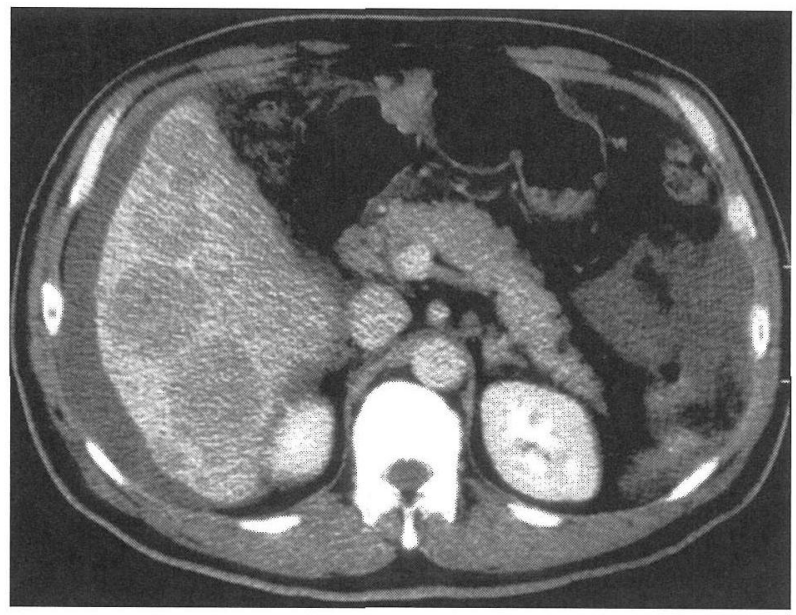

図 2 腹部造影 CT 所見（軸位断）

肝内に全区域にわたって多発性の低吸収域を認める。ま た腹水の貯留を認める。

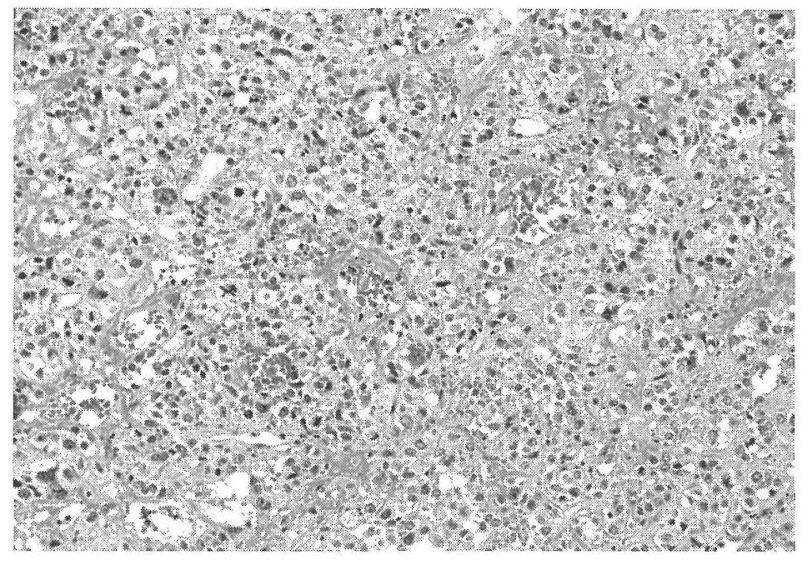

図 3 左口盍扁桃の病理組織学的所見 (HE 染色, 50 倍像) 高度の異型核および淡明な細胞質を有する腫瘍細胞が全 体的に充実性に増殖し, 一部では索状配列を認める。

骨転移と診断した。消化器内科医師と合同で患者と家族 一病名を告知した。また治療に関して根治は困難だが， 口蓋扁桃腫湯による嚥下障害や疼痛，出血を軽減でき， QOL を改善することができる可能性のある治療として 口蓋扁桃摘出術を提示した。手術によるリスクも説明し た。しかし患者と家族は栄養補給や薬物による疼痛コン トロール等の緩和療法を希望した。入院後 3 週目から経 口摂取が不可となり, 中心静脈栄養下の管理となった。 口蓋扁桃腫瘍から 2 回の出血を認め，それぞれ輸液後の $\mathrm{Hb}$ 值からの推定で $1000 \mathrm{ml}$ 程度の出血と思われた. 止血

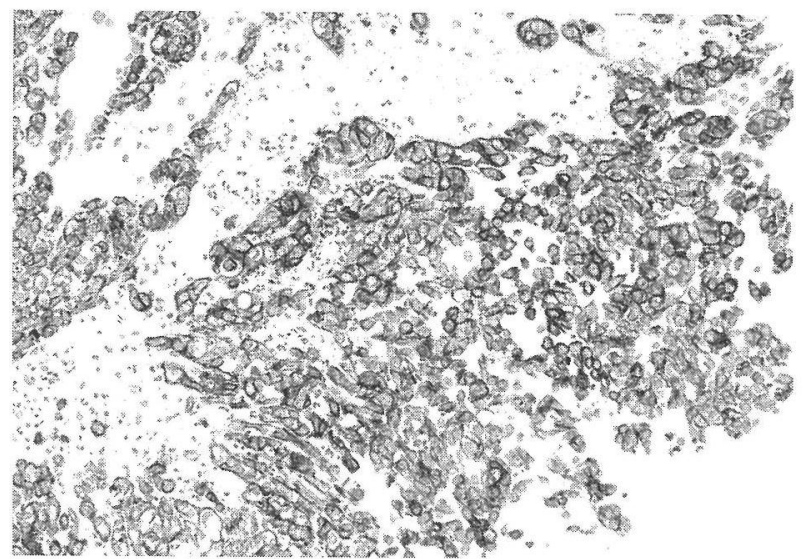

図 4 左口蓋扁桃の病理組織学的所見 (CAM5. 2 免疫染色，50 倍像)。

上皮系免疫染色の細胞膜と細胞質に染色性を認めてい

る。また間葉系免疫染色のビメンチンは染色されなかっ た.

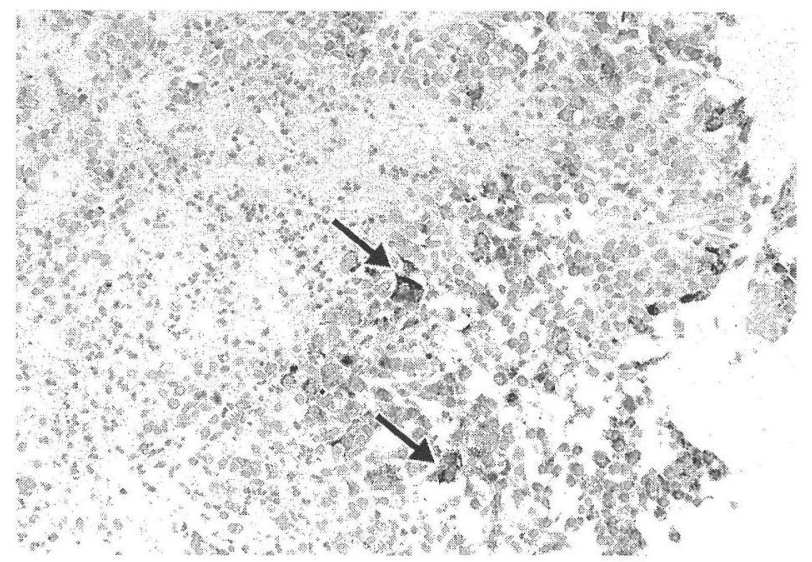

図 5 左口蓋扁桃の病理組織学的所見 (Hepatocyte 免疫染色, 50 倍像)

細胞質中に染色される顆粒を認める (矢印).

は 5000 倍ボスミン綿球での圧迫止血を行った。止血に難 渋し貿血が進行したが，輸血は行わなかった。入院から 6 週目に患者は肝不全のため死亡した。

病理解剖所見：原発巣である肝実質内に多発性の腫瘍 を認めた。門脈内にも腫瘍の浸潤を認めた（図 7)。病理 組織学的には, 肝臟原発巣は活発な分裂像を呈する N/C の高い腫瘍細胞がシート状〜胞栄状，一部偽腺管等の構 造異型を示す中〜低分化型相当の肝細胞癌の所見 (Edmondson 分類 ${ }^{11} \mathrm{II} \sim \mathrm{III}$ 相当）であった．左口蓋扁桃 と椎骨，肋骨，胸骨に多発性に転移を認めた。肺や消化 


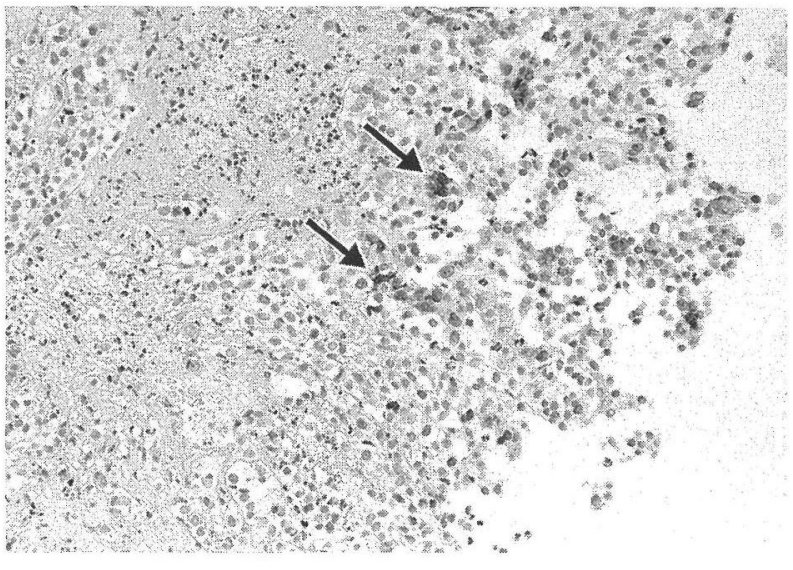

図 6 左口蓋扁桃の病理組織学的所見 (AFP 免疫染色, 50 倍像). 細胞質は顆粒状に染色される部分を認める (矢印).

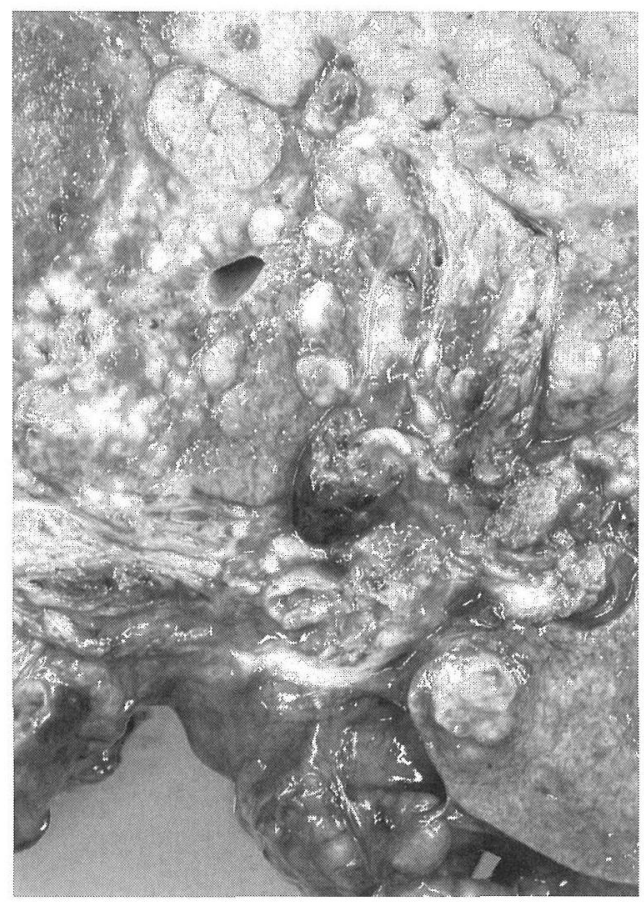

図 7 肝門部の肉眼的病理学的所見 肝門部付近と閒脈にも腫瘍の浸潤を認める。

管には肉眼上，明らかな転移を認めなかったが，病理組 織学的には毛細血管内に腫瘍の転移巣をびまん性，散在 性に多数認めた。肉眼上, 頸部リンパ節, 縱隔リンパ節, 肝門部リンパ節にリンパ節腫脹を認めたが，病理組織学 的に転移を認めたのは胃噴門部リンパ節と縦隔リンパ節 のみであった。

\section{考察}

口蓋扁桃に発生する悪性腫瘍はその多くが原発性の腫 瘍とされている。本症例は，初診時には口蓋扁桃の所見 と腹部 CT の所見より, 口蓋扁桃腫瘍を原発とする肝臓 への多発転移，もしくは口蓋扁桃の悪性リンパ腫を疑つ た。しかし初診時に生検した口盍扁桃の病理組織学的検 査（HE 染色像）では口蓋扁桃原発の悪性腫瘍とは異な る所見であった。肝臓あるいは腎蔵を原発とする腫瘍を 疑う所見であった。また免疫染色において，上皮系マー カーである CAM5. 5 により染色性を認めたこと，間葉系 マーカーであるビメンチンにて染色性が認められなかっ たことから悪性リンパ腫は否定的であった。肝細胞癌に 特異性の高い, Hepatocyte が陽性で AFP も局所的に染色 性を認めた。以上の結果より肝細胞癌の口蓋扁桃転移と 診断した。

口盖扁桃への他臓器からの転移はまれである。竹崎 ら 2) は口蓋扁桃へ転移をきたした原発巣について，肺癌 25 例 (38.5\%), 肝細胞癌 11 例 (15.4\%), 胃癌 8 例 (12.3\%), 大腸癌 3 例 $(4.6 \%)$, 皮膚悪性黒色腫 3 例 (4. 6\%)，腎細胞癌 2 例 $(3.1 \%)$ ，乳癌 2 例 (3.1\%)。䋐 毛癌 2 例 $(3.1 \%)$, その他胆囊癌, 肝臓癌, 子宮癌, 甲 状腺癌，悪性中皮腫，精上皮腫，胸腺腫，心平滑䇗肉腫， 大腸平滑筋肉腫がそれぞれ 1 例ずつであったと報告して いる ${ }^{2)}$. 口蓋扁桃への転移がまれな理由は，扁桃には輸 入リンパ管が存在しないこと ${ }^{3)}$, 病理解剖時に口蓋扁桃 の精査が必ずしも十分になされていないこと4)，扁桃は 細網内皮系細胞が多く腫瘍細胞を排除する能力があるこ と5)等が考えられている。

本症例の左口盍扁桃への転移経路法口盖扁桃に瀭入 リンパ管がないこと，閒脈内に腫瘍の浸潤がみられたこ とから血行性転移と思われた。また肝細胞癌が血行性転 移をきたす際，肺への転移も $47.3 \%$ と高率を示すとされ ている6)。その他の報告でも他臓器悪性腫瘍から扁桃へ の血行性転移には，原則として肺転移を形成するとされ ている7)。本症例においても肺に転移巣を多数認め，口 蓋扁桃への血行性転移を示唆する所見として矛盾しな い.

本症例は先に転移巣である口蓋扁桃腫瘍がみつかり， 転移栄の病理組織学的診断により肝細胞癌の口蓋扁桃転 移と判明した。HE 染色の結果が判明した際に病理医よ り耳鼻咽喉科医へ連絡があり，肝機能異常があること， 画像検查で肝臓に腫瘤があることを病理医に伝えること 
ができた。 そのため肝細胞癌に特異性の高い免疫染色を 行い，速やかに原発巣を同定することができた．転移巣 が先にみつかり原発巣が同定困難な症例では，病理医と 密接に連携をとることで速やかに確定診断につなげるこ とが大切であると思われた。

他藏器の悪性腫湯から頭頸部領域への転移がある症例 に関しては，先に転移巣がみつかる場合，転移巣の診断 がついてから 1 年生存する確率は $25 \%$ と不良である ${ }^{8)}$. そのため患者が積極的な治療を希望しなかったことは一 つの選択である．また末期であっても患者の QOL を改 善する可能性があれば，外科手術等の積極的な治療をす るのがよいという意見もある9）が，本症例では血液凝固 能や全身状態，また患者の希望を考慮すると適応ではな いと考えた。しかし症例によっては積極的に治療を検討 すべき場合もあると考えられた。

\section{まとめ}

1）口蓋扁桃へ転移した肝細胞癌の 1 例を報告した.

2）耳鼻咽喉科医と病理医との密な連携により速やか に診断することができた。

3）本症例の転移経路は血行性転移と思われた。

4）患者の QOL を改善するためには状況が許せば，積 極的な治療も考慮されるが本症例では行わなかった.

本論文の要旨は第 127 回日耳鼻神奈川県地方部会（2004 年 3 月，横浜市）にて報告した。
本論文は岡本牧人教授就任 10 年を記念するものである.

\section{参考文献}

1）日本肝癌研究会（編）：臨床・病理 原発性肝癌取扱い規 約，金原出版，東京，1987.

2）竹崎英一，村上信三，津田敏孝，他：肝細胞癌口蓋扁桃転 移の 1 例. 綜合臨 $47: 3031 \sim 3033,1998$.

3）斉藤英雄, 飯田信長, 山田勝彦, 他 : 両口蓋扁桃に転移を 見を肺癌症例. 日気食会報 7:42 47, 1956.

4）田中憲雄，東家倫夫，小柳義夫：胃癌よりの転移性口蓋扁 桃腫瘍の 1 症例.耳鼻 $27: 811 \sim 814 ， 1981$.

5）船井洋光, 船坂宗太郎, 山口宏也, 他：転移性扁桃腫場の 1 例. 耳喉 $53: 421 \sim 423,1981$.

6）奥平雅彦, 高田伸一, 金子 聡, 他：原発性肝癌の転移. 日臨 $46: 67 \sim 75,1988$.

7）上田征吾, 小林吉史, 長峯正泰, 他 : 肝細胞癌口蓋扁桃転 移の 1 例. 口咽科 $13: 353 \sim 357,2001$.

8）中山貴子, 高橋廣臣：他臓器悪性腫瘍と耳鼻咽喉科。耳喉 頭頸 $72: 233 \sim 236,2000$.

9) Nakahara K, Matuo S, Takeuchi H, et al. : A case of hepatocellular carcinoma metastasizing to the palatine tonsil. Yongo Acta medica $42: 217 \sim 220,1999$.

原稿受付：平成18年 4 月 10 日

原稿採択：平成18年 7 月 6 日

別刷請求先 : 清野由輩

T242-8602 神奈川県大和市深見西8-3-6

大和市立病院耳鼻咽喉科 